Marko Ristić ${ }^{1, a}$, Ivana Vasović ${ }^{1, b}$, Vladimir Bošković ${ }^{1, c}$, Christof Sommitsch ${ }^{2, c}$, Jasmina Perišić , $^{1, a}$

\title{
Analysis of the influence of different types of coatings on increasing the working life of constructional elements of the ventilation mill and reducing the wear of working surfaces
} Analiza uticaja različitih vrsta obloga na povećanje radnog veka konstrukcionih elemenata ventilacionog mlina i smanjenje trošenja radnih površina

Originalni naučni rad / Original scientific paper Rad je u izvornom obliku objavljen u Zborniku sa 4. IIW Kongresa zavarivanja Jugoistočne Evrope „Safe Welded Construction by High Quality Welding" održanog u Beogradu 10-13. Oktobra 2018

\section{Rad primljen / Paper received:}

April 2019.

Ključne reči: ventilacioni mlin, trošenje, prevlake-obloge, višefazni tok, nanošenje, radni vek

\section{Rezime}

U radu su analizirane mogućnosti povećanja otpornosti na habanje delova ventilacionog mlina za mlevenje uglja u elektranama, analizom sa multidisciplinarnim istraživanjima. Delovi ventilacionog mlina izloženi su veoma složenim radnim uslovima (velika brzina čestica, prisustvo peska do $40 \%$ i druge mineralne komponente). Upotrebom CFD 3D numeričke simulacije višefaznog toka u mlinu, analizirana je brzina, koncentracija i ugao protoka smese oko radnih delova. Analizirajući potencijalnu primenu obloga otpornih na habanje na radnim delovima ventilacionog mlina, ima za cilj da poveća preostali radni vek radnih elemenata. Analizirajući oštećene delove ventilacionog mlina i koristeći numeričku simulaciju oko radnih elemenata, odabrana je široka paleta dodatnih materijala otpornih na habanje za eksperimentalna ispitivanja. Za analizu mogućnosti poboljšanja svojstava površine, obloge otporne na habanje nanose se različitim tehnikama: ručnim elektrolučnim zavarivanjem, HVOF talozima i plazma zavarivanjem, a koriste se i dodatni materijali različitih hemijskih sastava. Struktura uzoraka se analizira sa SEM-EDS i merenjem i distribucijom tvrdoće u presecima uzoraka. Verifikacija analiziranog rezultata vrši se eksperimentalnim ispitivanjem, sprovođenjem simulacije trošenja $u$ ventilacionom mlinu na uzorcima u komori mašina za peskarenje. Medijum za simulaciju habanja je kvarcni pesak i uzorci su postavljeni pod uglom od $20^{\circ}$. Primena ovog istraživanja može povećati radni vek delova u termoenergetskim objektima, smanjiti broj mogućih

\author{
Adresa autora / Author's address: \\ a Institute Mihailo Pupin , Volgina 15 Belgrade, Serbia \\ ${ }^{b}$ Lola Institute, Kneza Višeslava 70a , Belgrade, Serbia \\ ${ }^{c}$ Institute of Materials Science, Joining and Forming, \\ Kopernikusgasse 24/l 8010 Graz, Austria, \\ "Union - Nikola Tesla" University, Cara Dušana 62-64, \\ Belgrade, Serbia
}

Key words: ventilation mill, wear, coatings, multiphase flow, depositions, working life

\begin{abstract}
Research presented in this paper analyzed the possibilities of increasing the wear resistance of the ventilation mill parts for coal grinding in power plants, analyzing with multidisciplinary research. The parts of ventilation mill are exposed in very complex working condition (high velocity of particles, presence of sand up $40 \%$ and other mineral components). Using the CFD 3D numerical simulation of multiphase flow in grinding mill, is analyzed the speed, concentration and flow angle of mixture around working parts. Analyzing the potential application of wear resistance coating on the working parts ventilation mill have goal to increase remaining working life of working elements. By analyzing the damaged parts of ventilation mill and using the numerical simulation around working elements, are selected wide pallet of wear resistance filer materials for experimental testing. To analyze possibilities to improve surface properties, the wear-resistant coatings were deposited by various technologies: manual metal arc welding, HVOF depositions and plasma welding and also are used filler materials with different chemical compositions. Samples structure is analyzed with SEM-EDS and also by measurement and distribution of hardness in the samples crosssections. Verification of analyzed result is done by experimental testing, performing simulation of wear in ventilation mill on the samples in sandblasting machines chamber. Medium for simulating wear is quartz sand and the samples are positioned at angle $20^{\circ}$. Application of this research can increase working life of parts in termoenergetic facilities, reduce the number of possible repairs and extends
\end{abstract}


popravki i produžiti period između njih. Time se postižu značajni ekonomski efekti.

\section{Uvod}

Nema sumnje da je energija oblast od posebnog značaja za čitavu privredu i društvo. Ako je proizvodnja energije stabilna kao moderan i dobro organizovan sektor, sigurno je da će to značiti dobro za celokupnu privredu zemlje. Nasuprot tome, ako se energiji ne posveti dovoljno pažnje sa stanovišta strateškog planiranja, postoji određena slaba pozicija i slabi izgledi privrede u celini [1]. Najverovatniji scenario globalnog razvoja pretpostavlja ekonomiju zasnovanu na efikasnoj upotrebi relativno "čistih" i iz različitih izvora, raspoložive energije. Prema svim razvojnim scenarijima postoji tendencija smanjenja energetske intenzivnosti ili potrošnje po jedinici novčanog proizvoda [1-3]. Glavni cilj ovog rada je da analizira mogućnost povećanja otpornosti na habanje delova ventilacionog mlina za mlevenje uglja u elektranama. Ovom analizom biće izabrana optimalna tehnologija za nanošenje prevlakaobloga radnih delova koji su izloženi oštećenjima i habanju. Materijali i konstrukcije u rudarskim i energetskim industrijama oštećuju se pod uticajem brojnih faktora, kao što su: različita mehanička naprezanja, povišena-niska temperatura, sastav i atmosferski uslovi, oblici i dimenzije dela ili konstrukcije; struktura i svojstva materijala i kvaliteta površine [1,2]. Svi ti faktori pojedinačno utiču na radni vek materijala i konstrukcija, ali mnogo veći uticaj imaju u međusobnoj interakciji. Danas razvoj i projektovanje nije moguće bez korišćenja raznih 3D programa za modeliranje i za analizu struktura i ponašanja delova i konstrukcija. Optimizacija konstrukcije sa numeričkim analizama je dobro poznat pristup za poboljšanje performansi proizvoda koji se koriste u svim granama nauke i industrije $[3,4]$. Pristup ovom radu je objedinjavanje multidisciplinarnih istraživanja ventilacionih mlinova termoelektrana, koji uključuju različite teorijske, numeričke, empirijske i eksperimentalne metode [58]. U dostupnoj literaturi prikazana je upotreba numeričkih metoda za različite aplikacije širom sveta, što dovodi do optimizacije kompleksnog sistema. [9]

Ovo istraživanje je nastavilo prethodna istraživanja koja su sprovedena za druge radne delove ventilacionog mlina. Udarne ploče ventilacionog mlina su već redizajnirane i potvrdile su da je numerička simulacija dobar alat za smanjenje broja modalnih eksperimenata i za precizniju analizu procesa koji se javljaju tokom kompleksnog toka koji mogu ukazati na potencijalnu metodologiju redizajna. [9] the period between them. This achieves significant economic effects.

\section{Introduction}

There is no doubt that energy is a field of special importance for the entire economy and society. If energy producing is stabile as modern and wellorganized sector, it is certain that this will mean good for the entire economy of the country. Conversely, if energy is not given enough attention from the strategic planning point of view there is a certain weak position and weak prospects of the economy as a whole [1]. The most likely scenario of global development assumes an economy based on the efficient use of relatively "pure" and from various sources of available energy. According to all development scenarios have tendency of decreasing energy intensity or spending per unit of money product [1-3]. The main aim of this paper is, to analyses the possibility of increasing the wear resistance the parts of ventilation mill for coal grinding in power plants. By this analysis it will be selected optimal technology for coating of working parts which are exposed to damages and wear. Materials and construction in mining and energetic industries damages under the influence of numerous factors, such as: various mechanical stresses, elevated-low temperature, composition and atmospheric conditions, shapes and dimension ns of a part or construction; structure and properties of material and quality of surface $[1,2]$. All those factors have individually effect on the working life of materials and constructions but much higher influence have in mutual interaction. Today development and designing is not possible without using various 3D programs for modeling and for analyses of structures and behavior of parts and constructions. Construction optimization with numerical analyses is a well-known approach for improving product performances which are used in all branches of science and industry [3, 4]. Approach of this paper is to unite multidisciplinary research of ventilation mills of thermal power plants includes a variety of theoretical, numerical, empirical and experimental methods [5-8]. The available literature shows the worldwide usage of numerical methods for different applications leading to optimization of the complex system. [9] This research has continued the previous research which conducted for other working parts of ventilation mill. Impact plates of ventilation mill is already redesigned and confirmed that numerical simulation is a good tool for reducing the number of modal experiments and for more precise analysis of process which occur during the complex flow which can indicate potential redesign methodology. [9] 
CFD studija višefaznog toka pomoću Euler-Eulerovog modela smeše predstavljena je $u$ referencama $[1,2,6,8]$. Višestruki protok smeše u ventilacionom postrojenju čine vazduh, ugalj, pesak i druge mineralne čestice. Problem nosivosti radnih delova ventilacionog mlina javlja se tokom visokog prisustva peska u smeši, procenat peska zavisi od kvaliteta uglja i ne može se uticati na njega. Procenat peska u smeši može biti do $40 \%$ uglja. Zbog velike brzine čestica peska dolazi do izraženog trošenja elemenata brusnog točka i zidova mlina, smanjujući vremenski period između dve popravke i njihovog životnog veka.

$U$ ovom radu analizirana je interakcija svih čestica sa površinom radnih delova ventilacionog mlina u dvofaznom sistemu gasu - čvrste čestice. Na ovaj način će se prikazati i analizirati strujanje oko kućice ventilacionog mlina oko elementa koji daje dodatno brušenje i postavlja se na kućicu mlina. Oštećenja se indirektno određuju na osnovu rezultata numeričke simulacije protoka; vektori brzine i raspodele čestica u kućnom ventilacionom mlinu. [1-3, 6-10].

$\mathrm{Za}$ povećanje radnog veka elementa $\mathrm{u}$ ventilacionom mlinu koristi se proces oblaganja. Koriste se originalni radni delovi i obloženi su samo materijalom koji ima otpornost na habanje. Oblaganje predstavlja pouzdanu metodu površinske obrade, koja je odabrana za poboljšanje površinskih svojstava materijala radnih delova, u kojem naneti materijal daje druge karakteristike originalnim radnim delovima. Za potrebe ovog istraživanja, upotrebljeni sloj koji ima odličnu otpornost na habanje i oksidaciju, homogeno se nanosi na površinu podloge [3-5, 11].

Analiza prethodnih eksperimentalnih istraživanja pokazala je linearnu zavisnost otpornosti na abrazivno trošenje i mehaničkih svojstava materijala. [8, 10-14] $\mathrm{Na}$ osnovu mehaničkih svojstava, posebno tvrdoće, može se predvideti ponašanje metala u uslovima habanja, ali tvrdoća nije jedina karakteristika koja utiče na otpornost na habanje i trošenje uopšte. Parametri, koji takođe utiču na otpornost na habanje, su struktura, oblik, veličina i raspored mikrokonstituenata u nanetom sloju [8-12].

Izbor optimalnih postupaka oblaganja, dodatnih materijala i tehnologije nanošenja vrši se na osnovu rezultata numeričkih simulacija, strukturnih i mehaničkih analiza uzoraka iz modela eksperimentalnog oblaganja.

Elementi prepreka u kućici ventilacionog mlina (položaj je prikazan strelicama na slici 1). Elementi prepreka se nalaze u kućici ventilacionog mlina između radnog točka i kućice ventilacionog mlina i
CFD study of the multiphase flow by using a EulerEuler, mixture model is presented in references [1, $2,6,8]$. Multiphase flow of mixture in ventilation mill consist form air, coal, sand and other mineral particles. Problem of wears working parts of ventilation mill occur during the high presence of sand in the mixture, percentage of sand depend form coal quality and cannot be influence on it. Percentage of sand in the mixture can be up to $40 \%$ of coal. Due to the high velocity of sand particles, pronounced wear of the grinding wheel elements and mill walls occurs, decreasing the time period between the two repairs and their lifespan.

The all particles interaction is analyzed with the surface of working parts of ventilation mill in a twophase gas-solid particle flow are analyzed in this paper. In this appear it will have presented and analyzed flow around house of ventilation mill around the element which give additional grinding and positioned on house of mill. Damages are indirectly determined based on the results of the flow numerical simulation; vectors of the velocity and distribution of particles in the house ventilation mill. [1-3, 6-10].

For increasing the working life of element in ventilation mill is used coating process. It's used original working parts and only coated with material which have resistance to wear. Coating present reliable surface treatment method, which selected to improve the surface properties of working parts material, in which a coated material, give the others characteristic to original working parts. For the purpose of this research is a used coat that has excellent resistance to wear and oxidation, is homogeneously deposited onto the surface of a substrate $[3-5,11]$.

Analyzing the previous experimental research has indicated a linear dependence of abrasive wear resistance and mechanical properties of materials. $[8,10-14]$ Based on the mechanical properties, especially hardness, the behavior of metals in the conditions of wearing can be predicted, but hardness is not the only characteristic that affects the wear resistance and wear in general. Parameters, which also affect the wear resistance, are the structure, shape, size and distribution of microconstituents in the coating [8-12].

The selection of optimal coating procedures, filer materials and coating technology is done based on the results of numerical simulation, structural and mechanical analyses of samples from experimental coating model.

The obstacles elements in house of ventilation mill (position is shown by arrows Figure 1). Obstacles elements are located at the house of ventilation mill 
mogu povećati efekat rešetke i generalno efikasnost ventilacionog mlina.

Elementi prepreka povećavaju finoću mlevenja ugljena, ali i smanjuju kapacitet ventilacionog mlina, stoga je potrebno ukloniti separator ugljene prašine iz mlina. $\mathrm{Na}$ taj način, proces protoka mlevenog uglja u ventilacionom mlinu sa elementima prepreka, značajno smanjuje trošenje radnih elemenata mlina, a posebno radnih kola sa udarnim pločama, produžava radno vreme ovih mlinova i poboljšava proces sušenja ugljene prašine.

Prethodna istraživanja ukazuju da povećanje broja prepreka povećava broj mogućih sudara čestica ugljene prašine i na taj način povećava efikasnost brušenja. Takođe, na efikasnost brušenja može uticati povećanje dimenzija prepreka kao i smanjenje rastojanja između radnog točka i kućice ventilacionog mlina (smanjujući prosečni prečnik položaja prepreka).

Primer uspešne rekonstrukcije kombinovanog ventilacionog mlina DGS 100S, koji se nalazi u TE Nikola Tesla A u Obrenovcu, detaljno je opisan u literaturi. [3, 4, 14] Cilj rekonstrukcije je postizanje povećanog mlevenja uglja. Ploče su postavljene u spiralu kućice ventilacionog mlina kao prepreka na izlazu iz mlina do područja kanala za prašinu.

Dalji eksperiment je sproveden kako bi se povećao broj prepreka smeštenih u kućici ventilacionog mlina. Testovi su izvedeni sa 9, 10, 11, 12, 14, 15, 24 i 25 elementima prepreka. Postavljeni su u nizu sa udarnim točkom, počevši od izlaza ventilacionog mlina do kanala za prašinu, povećavajući njihov broj na jednu tačku gde svih 25 prepreka pokrivaju celu kućicu ventilacionog mlina

Za simulaciju procesa trošenja koriste se mašine za peskiranje. Verifikacija analiziranog rezultata vrši se eksperimentalnim ispitivanjem na uzorcima $u$ komori mašine za peskiranje. Medijum za simulaciju habanja je kvarcni pesak i uzorci su postavljeni pod uglom od $20^{\circ}$.

\section{Numerička simulacija $i$ analiza rezultata modela smše}

Numerička simulacija višefaznog toka u ovom istraživanju, predstavlja prvi korak u identifikaciji mogućnosti za revitalizaciju delova mlina izloženih habanju. Analizirajući vektor brzine i raspodelu protočnih mešavina, tj. čestice, moguće je locirati kritične tačke $u$ konstrukciji ventilacionog mlina. Karakter višefaznog toka u ventilacionom mlinu TEKostolac B, u kome učestvuju komponente between working wheel and house of ventilation mill and they can increase effect of gridding and generally the ventilation mill efficiency.

The obstacles elements increase the fineness of grinding of coal but it also reduces the ventilation capacity of the mill, therefore, it is necessary to remove the coal dust separator from the mill. In this way, the flow process of coal grinding in a ventilation mill with obstacles elements significantly reduces the wear of the working elements of the mill and especially the working wheel wit impact plates extend working time of these mills and improves the process of coal dust drying.

Previous research indicates that increasing the number of obstacles elements increases the number of possible collisions of coal dust particles and in this way increases the efficiency of grinding. Also, the grinding efficiency can be influenced by increasing the dimensions of the obstacles as well as by reducing the distance between the working wheel and house of ventilation mill (reducing the average diameter of position of obstacles elements). An example of a successful reconstruction of the combined ventilation mill DGS 100S, which is located at the TE Nikola Tesla A in Obrenovac, is described in detail in the literature. $[3,4,14]$ The goal of the reconstruction is to achieve an increase grinding of coal. The plates were placed in the spiral of the ventilation mill house as an obstacle at the exit from ventilation mill to area of dust channel. Further experiment was carried out in order to increase the number of obstacles placed in the house of ventilation mill. The tests were carried out with 9, 10, 11, 12, 14, 15, 24 and 25 obstacles elements. They were placed in a row with the impact wheel starting from the exit of ventilation mill to the dust channel, increasing their number to one point where whole 25 obstacles cover whole house of ventilation mill.

To simulate the process of wear is used sandblasting machines. Verification of analyzed result is done by experimental testing perform at the samples in sandblasting machines chamber. Medium for simulating wear is quartz sand and the samples are positioned at angle $20^{\circ}$.

\section{Numerical simulation and analyses of results mixture model}

The numerical simulation of the multiphase flow in this research present the first step in identifying possibilities for revitalization of the mill parts exposed to wear. By analyzing the velocity vector and the distribution of flow mixtures, i.e. particles, it is possible to locate the critical points in the construction of the ventilation mill. Character of multiphase flow in the ventilation mill TE-Kostolac 
vazduha, ugljene prašine, peska i drugih minerala, direktno je povezan sa ranom funkcijom ventilacione efikasnosti mlina, kao i sa procesom habanja vitalnih delova. Promene u kvalitetu i protoku parametara mešavine direktno utiču na promene u komori za sagorevanje i kotlarnici. Programski paket ANSIS FLUENT zasnovan na metodi konačne zapremine koristi se za numeričke simulacije protoka.

Rejnoldsove prosečne Navier-Stokesove parcijalne diferencijalne jednačine turbulentnog višefaznog toka u mlinu rešene su. Dobijeno je rešenje disperzovanog gasa - čvrste struje, gde su granularne faze praškaste čestice lignita i peska. Vlaga uglja se uvodi kao gasna faza [1-6]. Numerička simulacija višefaznog toka u ventilacionom mlinu sa preprekama prvi je korak u istraživanju uticaja prepreka na zidu mlina na karakteristike ventilacionog mlina i izbor geometrije prepreka. Za potrebe ovog istraživanja koristi se numerička simulacija za analizu protoka u ventilacionom mlinu, za dva modela i šest geometrija sa različitim položajem i uglom prepreke. Prepreke elementa mlina su predstavile ploče na zidu ventilacionog mlina koje imaju za cilj povećanje efekta rešetke. Lokacija ovih prepreka prikazana je na slici 1. Lagranžovski pristup (DPM) ubrizgava čestice čvrste faze i prati njihovo kretanje u gasnoj fazi. Prva generiše potrebnu geometriju, tj. oblik udarnih ploča i elemenata prepreka, kao i njihov položaj i međusobnu udaljenost. $U$ drugom koraku, mreža se generiše u numeričkom domenu. Treći korak obuhvata izbor višefaznog modela, definisanje primarne i sekundarne faze, definisanje graničnih i početnih uslova, turbulentnog modela, numeričku simulaciju do konvergencije rešenja $i$ analizu dobijenih rezultata.

Efikasnost brušenja u ventilacionom mlinu zavisi, pre svega od veličine kinetičke energije koja se prenosi na čestice uglja u njihovim sudarima sa udarnim elementima pokretača. $U$ ventilacionim mlinovima, sudari se javljaju pretežno na ulaznoj ivici udarne ploče pri brzinama koje su približno jednake prosečnoj brzini ploče na tački kontakta čestica u rasponu od 50-60 m/s. Dalje mljevenje se odvija trenjem čestica na udarnoj površini kada se kreće prema izlaznom rubu ploče. Drobljene i sušene čestice uglja, koje su prošle kroz udarne ploče ventilacionog mlina, dosežu apsolutnu brzinu na izlazu od $80-100 \mathrm{~m} / \mathrm{s}$.
$B$, where components of air, coal dust, sand and other minerals particles participate, is directly related to the operation function of the ventilation efficiency of the mill, as well as to the wear process of vital parts. Changes in quality and flow of the mixture parameters directly affect changes in the combustion chamber and boiler plant. The ANSYS FLUENT software package based on the finite volume method is used for numerical flow simulations.

The Reynolds averaged Navier-Stokes partial differential equations of the turbulent multiphase flow in the mill are solved. A solution of the dispersed gas-solid flow is obtained, where granular phases are pulverized lignite and sand particles. The coal moisture is introduced as gas phase [1-6]. Numerical simulation of multiphase flow in a ventilation mill with obstacles is the first step in exploring the impact of obstacles on the wall of mill on the characteristics of the ventilation mill and the selection of the geometry of obstacles. For the purpose of this research numerical simulation is used to analyze flow in ventilation mill, for the two models and six geometries of with different position and angle of obstacles elements. Obstacles elements of mill have presented the plates on the wall of ventilation mill which have purpose to increase the effect of gridding. Location of these obstacles is shown on Figure 1. Lagrangian approach (DPM) injects solid phase particles and monitors their motion in the gaseous phase. The first generates the required geometry, that is, the shape of the impact plates and obstacles elements, as well as their position and mutual distance. In the second step, a network is generated in the numeric domain. The third step involves the choice of a multiphase model, the definition of primary and secondary phases, the definition of boundary and initial conditions, a turbulent model, numerical simulation to the convergence of the solution, and analyzes the obtained results.

The efficiency of grinding in ventilation mill depends primarily on the size of the kinetic energy that is passed on to coal particles in their collisions with impact elements of the impeller. In ventilation mills, collisions occur predominantly at the input edge of the impact plate at speeds approximately equal to the average velocity of the plate at the particle contact point in the range of $50-60 \mathrm{~m} / \mathrm{s}$. Further grinding takes place by friction of the particles on the impact surface when moving it towards the outlet edge of the plate. Crushed and dried coal particles, which passed through the impact plates of the ventilation mill, reach the absolute speed at an output of $80-100 \mathrm{~m} / \mathrm{s}$. 


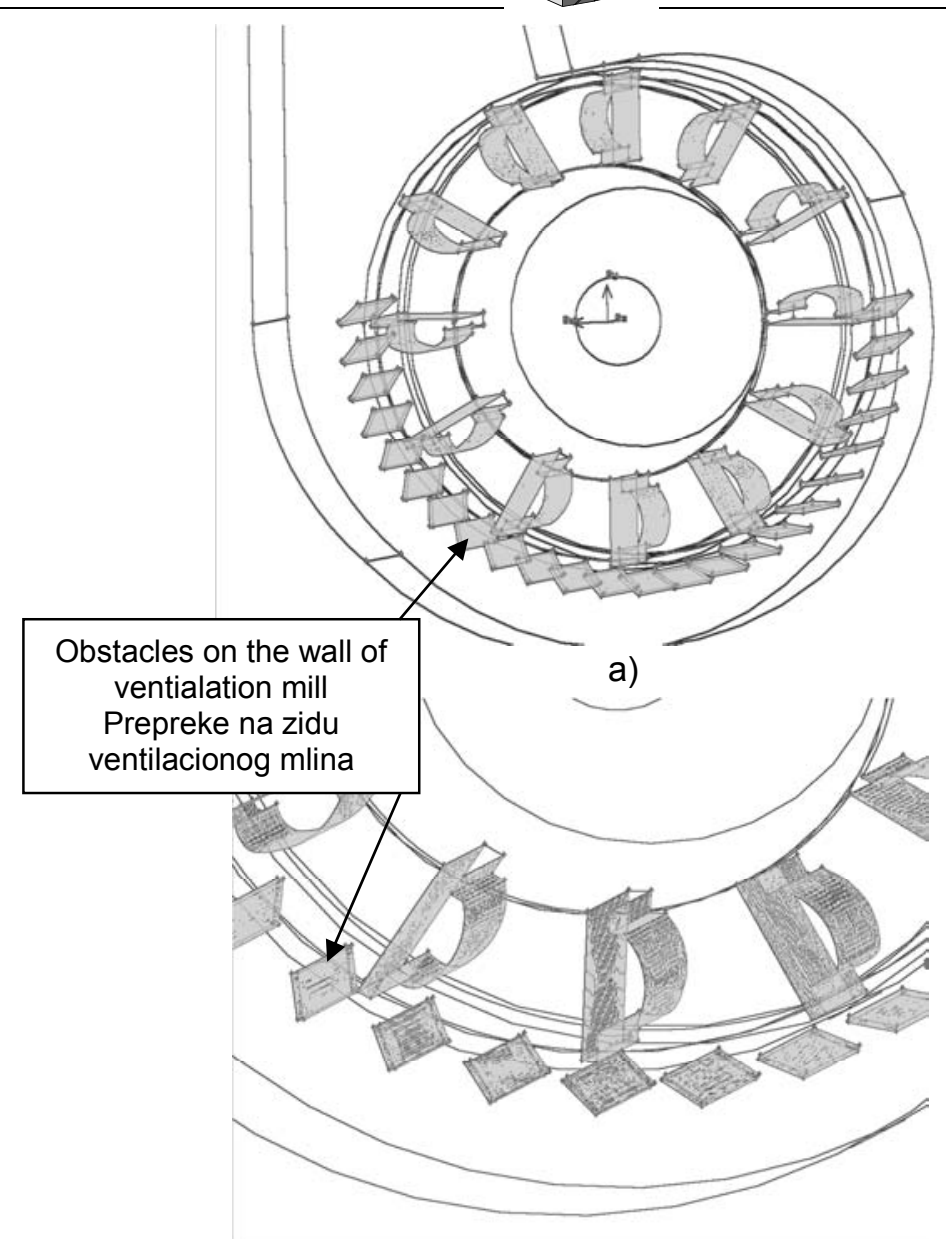

b)

Slika 1. a) Geometrijski model ventilacionog mlina sa kanalom i komorama do ulaza u gorionik, b) Rotorsko kolo sa udarnim i usisnim pločama (strelice označavaju lokacije usisnih ploča)

Figure 1. a) The geometric model of the ventilation mill with duct and channels to the entrance at the burner, b) Impeller wheel with impact and suction plates (arrows indicates locations of suction plates)

Za DPM dodavanje uglja, korišćena je RosinRamller-ova distribucija za četiri intervala prečnika: od 0 do $90 \mathrm{~mm}$, od 90 do $200 \mathrm{~mm}$, od 200 do 500 $\mathrm{mm}$ i od 500 do $1000 \mathrm{~mm}$. Procentualno prisustvo za ova četiri intervala ispunjava zahtev da normalno oko $80 \%$ čestica praškastog uglja ima prečnik do $300 \mathrm{~mm}$, tako da je srednji prečnik 152 $\mathrm{mm}$ i da parametar rasipanja ima vrednost 1.5227 . Korišćene su tri veličine čestica: 300 mm, 800 mm i $1500 \mathrm{~mm}$, pri čemu su čestice ubrizgane svakim od ova tri prečnika pojedinačno, a istovremeno ubrizgavanje čestica iz sva tri prečnika.

$\mathrm{Na}$ slici 2 prikazana je putanja čestica ugljene prašine za elemente prepreka pod uglom od $45^{\circ} \mathrm{i}$ centralnim uglom od $8^{\circ}$, a staze su obojene zavisno od prečnika čestica. Može se videti da povećanje veličine čestica povećava broj njihovih uticaja na elemente prepreka, dok manje čestice, zbog manje inercije, bliže prate protok gasne faze, ili se kreću duž obima mlina i imaju manje uglova odbacivanja. u kanalu za prašinu.
For the DPM coal injection, Rosin-Ramller distribution was used for four intervals of diameter: from 0 to $90 \mu \mathrm{m}$, from 90 to $200 \mu \mathrm{m}$, from 200 to $500 \mu \mathrm{m}$ and from 500 to $1000 \mu \mathrm{m}$. The percentage presence for these four intervals fulfills the requirement that normally about $80 \%$ of coil powder particles have a diameter of up to $300 \mu \mathrm{m}$, so that the mean diameter is $152 \mu \mathrm{m}$ and the spreading parameter has a value of 1.5227 . Three sand sizes of particles were used: $300 \mu \mathrm{m}, 800 \mu \mathrm{m}$ and 1500 $\mu \mathrm{m}$, whereby particles were injected with each of these three diameters individually, and at the same time injection of particles from all three diameters.

Figure 2 shows the path of coal dust particles for obstacles elements at an angle of $45^{\circ}$ and a central angle of $8^{\circ}$, and the paths are colored by the particle diameter. It can be seen that increasing particle size increases the number of their impacts on obstacles elements, while smaller particles, due to less inertia, more closely monitor the flow of the gaseous phase, or move along the circumference of the mill and have fewer rejection angles in the dust channel. 


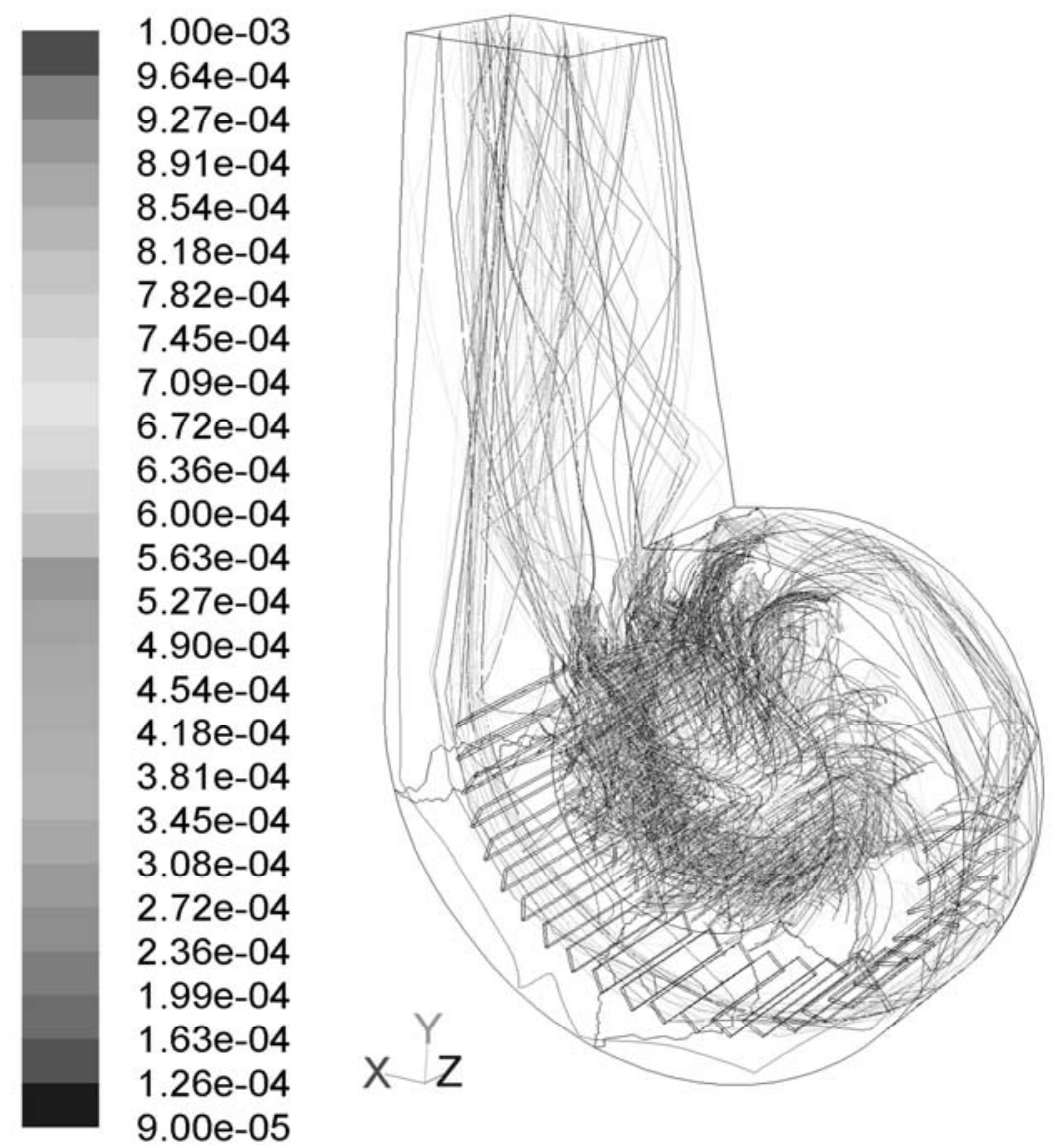

Slika 3. Putanja čestica ugljenog praha do elementa prepreka postavljenih pod $45^{\circ} i$ sa centralnim uglom od $8^{\circ}$, obojene putanje prečnika čestica

Figure 3. Path of the pulverized coal particles to obstacles element positioned under $45^{\circ}$ and with central angle of $8^{\circ}$, the paths of the colored particle diameter

Ovo je očiglednije kada se upoređuje sa česticama peska, zbog njihove mnogo veće inercije, a prikazano je na slici 4 elementa prepreka pod uglom od $55^{\circ}$ sa centralnim uglom od $8^{\circ}$, za sve prečnike, gde je putanja pokazuje intenzitet brzina čestica. Jasno se može uočiti da se putanje čestica peska od $300 \mu \mathrm{m}$ i $1500 \mu \mathrm{m}$ u delu mlina u kojoj postoje elementi prepreka, veoma razlikuju. Elementi prepreka sa svojim prisustvom dalje drobe čestice ugljene prašine kao i čestice mineralne materije, ali uz pad pritiska na izlazu iz kanala za prašinu.

Uticaj veličine čestica peska na putanju u ventilacionom mlinu i kanalu za prašinu, kada se istovremeno ubrizgavaju čestice iz sva tri prečnika, prikazan je na slici 4 . Slika 5 koja prikazuje putanje čestica u elementima prepreka potvrđuje da kako veličina čestica raste, povećava se i broj njihovih udara na elemente prepreka, dok manje čestica gotovo ne udaraju u barijere elementa prepreka, već se kreću praktično duž obima mlina.
This is more evident when is comparing to particles of sand, because of their much higher inertia, and is shown in Figure 4 of obstacles element at the angle of $55^{\circ}$ with the central angle of $8^{\circ}$,for all there diameter, where the path are colored particles speed intensity. It can be clearly observed that the trajectory of $300 \mu \mathrm{m}$ and $1500 \mu \mathrm{m}$ of sand particles in the part of the mill in which there are obstacles elements are very different. The obstacles elements with their presence further crumble the particles of coal dust as well as the particles of mineral matter, but with the pressure drop at the exit of the dust channel.

The influence of the sand particles size on a path in the ventilation mill and the dust channel, when simultaneously injecting particles from all three diameters is shown in Figure 4. Figure 5 showing the path of particles in the obstacles elements confirms that as the particle size increases, the number of their impacts on the obstacles elements increases, while fewer particles almost do not hit the barriers of obstacles elements but are moving practically along the mill circumference. 


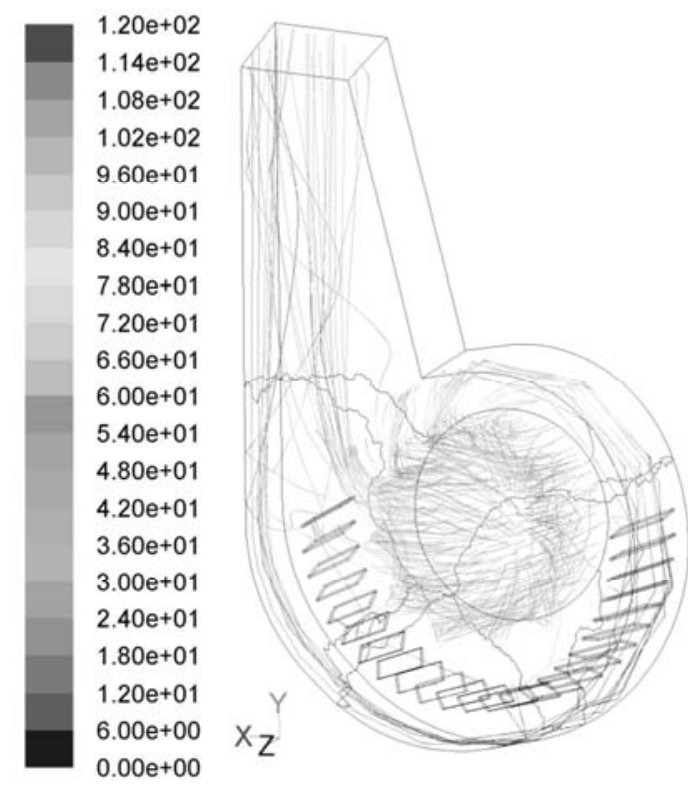

Slika 4. Putanja čestica peska sa elementom prepreke postavljenim pod $55^{\circ} i$ centralnim uglom od $8^{0}$, obojena putanja je za intenzitetom brzine čestica prečnika $300 \mu \mathrm{m}$

Figure 4. Path of sand particles with obstacles element positioned under $55^{\circ}$ and central angle of $8^{\circ}$, path are colored with speed intensity for particles diameter; $300 \mu \mathrm{m}$

\section{Modalne analize obloženih uzoraka}

Eksperimentalna modalna analiza je izvedena da bi se odabrale optimalne tehnologije prevlačenja radi povećanja radnog veka elemenata u ventilacionom mlinu. Brzina i pritisak iz numeričke simulacije identifikuju delove mlina koji su najviše izloženi habanju. Proces odabira optimalnih postupaka oblaganja, dodatnih materijala i tehnologije nanošenja koji će se koristiti u eksploatacionom stanju u kasnijoj fazi eksperimenta, uradiće se na osnovu rezultata numeričkih simulacija, strukturnih i mehaničkih svojstava uzoraka iz eksperimentalnog modela obloge koji je objašnjen u ovom poglavlju.

Prodor abrazivnih čestica i visoka tvrdoća obrnuto su proporcionalni tvrdoći površinskih slojeva $[3,22$, 30-32]. Parametri koji utiču na otpornost na habanje, pored tvrdoće, su struktura, oblik, veličina i distribucija mikro-sastojaka u nanetom sloju [3, 12-27]. Otpornost na habanje nantet legure zavisi od mnogih drugih faktora kao što su tip, oblik i raspodela tvrdih faza, kao i žilavost i otpornost matrice na naprezanje [4]. $U$ dosadašnjim istraživanjima analizirana je široka skala dodatnih materijala otpornih na habanje [12] i za potrebe ovog eksperimenta, jedna grupa dodatnih materijala za testiranje modela je odabrana i analizirana potencijalna implementacija $u$ funkcionalnom testiranju.

Urađeno je modalno ispitivanje makrostrukture, napravljeni su dijagrami raspodele tvrdoće, zona površinskog sloja i zone toplotne uticaja (HAZ). Mikrostrukturne analize su dobijene sken elektronskom mikroskopijom (SEM) i EDS

\section{Modal analyses of coated samples}

Experimental modal analysis is preformed to select optimal coating technologies to increase working life of elements in ventilation mill. Speed and pressure from numerical simulation has identify parts of mill which are the most exposed to wear. The process of selection the optimal coating procedures, filer materials and coating technology which will be used in exploitation condition in later stage of experiment, it will be done based on the results of numerical simulation, structural and mechanical properties of samples from experimental coating model which is explained in this chapter. The penetration of the abrasive particles and high hardness is inversely proportional to the hardness of the surface layers [3, 22, 30-32]. Parameters which effect on the wear resistance beside hardness are the structure, shape, size and distribution of micro constituents in the coated layer [3, 12-27]. The wear resistance of a coated alloy depends on many other factors such as the type, shape and distribution of hard phases, as well as the toughness and strain hardening behavior of the matrix [4]. In previous research wide scale of filler materials resistance to wear is analyzed [12] and for the purpose of this experiment, one group of filer material for model testing is selected and analyzed potential implementation in the functional testing.

Modal testing of macrostructure has been done, diagrams of distributions of hardness have been made, zone of the surface layer and Heat affected zone (HAZ). Microstructuaral analyses were 
analizom. Izbor dodatnog materijala i postupaka nanošenja koji će potencijalno koristiti i primenjivati u redizajnu radnih elemenata ventilacionog mlina se može postići iz rezultata ovog istraživanja.

Optimizacija performansi ventilacionog mlina postiže se korelacijom neizbežnog tehnološkog procesa i stanja glavnih radnih delova. Numerička simulacija višefaznog toka, zasnovana na raspoloživim parametrima, ukazuje na moduse loma komponenti sistema i olakšava uklanjanje uzroka.

\subsection{Eksperimentalni postupak modalnog testiranja}

Modalno ispitivanje se vrši na uzorcima obloženim adekvatnim slojem. Uzorci dimenzija 200x200x15 $\mathrm{mm}$, koji su napravljeni od toplo valjanog čeličnog lima S355J2G3 (ASTM 572), pripremljeni su i korišćeni kao supstrati. Da bi se sprečilo formiranje ukljućaka u nanetom materijalu, pre procesa nanošenja, uklonjeni su oksidni slojevi sa površine supstrata brušenema. Pre nanošenja, uzorci su prethodno zagrejani na $\mathrm{Tp}=160-170^{\circ} \mathrm{C}$. Korišćen je konvencionalni postupak nanošenja (zavarivanja): ručno elektrolučno zavarivanje (MMA) i zavarivanje punjeno žicom (FCAW), plazma nanošenje i HVOF (gasni plamen velike brzine High Velocity Oxi-Fuel) proces. Nakon procesa nanošenja, uzorci su hlađeni na vazduhu do sobne temperature.

Dodatni materijali, korišćeni u ovom radu, predstavljeni su u Tabeli 1 , sa postupcima za nanošenje, oznakama i nominalnim hemijskim sastavima kao i komercijalnim nazivom proizvođača Castolin Eutectic Co, Ltd, Beč. Najvažniji uslov procesa nanošenja je nizak stepen mešanja i proizvodni troškovi potrošnog materijala.. obtained with scanning electron microscopy (SEM) and with EDS analysis. The choice of filler materials and coating procedures which will potentially use and applied in the redesign of ventilation mill working elements it can be done from the results of this research.

Optimization of ventilation mill performances is achieved by correlating the inevitable technological process and the state of the main working parts. Numerical simulation of multiphase flow, based on the available parameters, indicated the modes of failure system components and facilitates the removing of causes.

\subsection{Experimental procedure of modal testing}

Modal testing is carried on the samples coated with adequate layer. Samples dimensions $200 \times 200 \times 15$ $\mathrm{mm}$, that are made of hot-rolled steel sheet S355J2G3 (ASTM 572), were prepared and used as substrates. In order to prevent the inclusion formation in the material deposits, prior to process of coating, the oxide layers were removed from the substrate surface by means of the grinding. Before coating, samples are preheated at $\mathrm{Tp}=160-170$ ${ }^{0} \mathrm{C}$. Conventional process of coating (welding) was used: manual metal arc welding (MMA) and flux core wire welding (FCAW), plasma coating, and HVOF (High Velocity Oxy-Fuel) process. After process of deposition samples with coatings were air-cooled down to the room temperature.

The filer materials, used in this paper, were presented in Table 1, with coating procedures, signs and nominal chemical compositions and commercial name manufactured by Castolin Eutectic Co, Ltd, Vienna. The most important condition of processes of deposition is that have low degree of mixing and the manufacturing cost of deposition consumables.

\begin{tabular}{|c|c|c|}
\hline $\begin{array}{c}\text { Coating } \\
\text { Material } \\
\text { Materijal za } \\
\text { nanošenje }\end{array}$ & $\begin{array}{c}\text { Nominal chemical } \\
\text { compositions } \\
\text { Nominalni hemijski sastav } \\
\left(\mathrm{M}^{\star} / \mathrm{C} \text { and M/Fe wt.\% ratio }\right)\end{array}$ & $\begin{array}{c}\text { Process } \\
\text { hardfacing } \\
\text { Postupak } \\
\text { tvrdog } \\
\text { navarivanja }\end{array}$ \\
\hline PG6503 & Ni-Cr-Bo-Si/ 60\% WC & $\begin{array}{c}\text { Plasma } \\
\text { process }\end{array}$ \\
\hline $55586 \mathrm{C}$ & $\mathrm{CoCrFeCW/WC}$ & HVOF \\
\hline $4010 \mathrm{EC}$ & $\begin{array}{c}\text { Fe-Cr-C-Si/Ti 0.18 (7.0 and } \\
0.6)\end{array}$ & MMA \\
\hline $4395 \mathrm{~N}$ & Fe-C-Cr-Ni-Mo-W-B & FCAW \\
\hline
\end{tabular}

Tabela 1. Materijali i postupci za nanošenje

Table 1. Materials and coating g procedures 


\subsubsection{Mikrostrukturna analiza $i$ ispitivanje tvrdoće}

Uzorci za analizu strukture i tvrdoće izrađeni su rezanjem vodenim mlazom u ravni upravnoj na površinu nanosa. Dobijeni poprečni preseci se bruse brusnim papirima SiC do P-1200 i poliraju suspenzijama glinice do $1 \mu \mathrm{m}$. Mikrostrukturna ispitivanja su izvedena na poliranim uzorcima nagriženim $3 \%$ nitalom. Mikrostrukture nanetih uzoraka su posmatrane skenirajućim elektronskim mikroskopom (SEM), a njihov hemijski sastav je ispitivan pomoću energetsko-disperzivne spektroskopije (EDS). SEM-EDS analiza je omogućila stvaranje elektronskih slika koje su omogućile morfološki opis različitih faza nanosa i EDS mape sastava korišćene za kvalitativno opisivanje hemijskih varijacija u mikrostrukturi. Takođe, merenja mikrotvrdoće u poprečnom preseku obloženih uzoraka napravljena su pomoću Vickersovog testa HV 10

\subsubsection{Microstructuaral Analysis and Hardness Test}

Samples for structure and hardness analyses were carried out by the water jet on the plane perpendicular to the coating surface. The obtained cross-sections are ground with $\mathrm{SiC}$ abrasive papers down to $\mathrm{P}-1200$ and polished with alumina suspensions down to $1 \mu \mathrm{m}$. Microstructuaral tests were carried out on polished samples etched with a solution of $3 \%$ Nital. The microstructures of coated specimens were observed by scanning electron microscope (SEM) and their chemical compositions were examined by energy-dispersive spectroscopy (EDS). The SEM-EDS analysis was creating electron imaging allowed different phase's morphologic description of the coatings and EDS compositional maps were used to qualitatively describe chemical variations in the microstructure. Also, the measurements of micro- hardness in the cross section of coated samples were made using a Vickers hardness tester HV 10.

\begin{tabular}{|c|c|c|c|}
\hline $\begin{array}{c}\text { Coating material } \\
\text { Naneti materijal }\end{array}$ & $\begin{array}{c}\text { Thickness of layer in } \mathrm{mm} \\
\text { Debljina sloja }\end{array}$ & $\begin{array}{c}\text { Degree of mixing, \% } \\
\text { Stepen mešanj }\end{array}$ & $\begin{array}{c}\text { Hardness, HV10 } \\
\text { Tvrdoća }\end{array}$ \\
\hline PG6503 & $\approx 4.5$ & 11 & $750-1049$ \\
\hline $55586 \mathrm{C}$ & $\approx 0.5-0.7$ & 10 & $644-701$ \\
\hline $4010 \mathrm{EC}$ & $\approx 5.2$ & 20 & $887-1028$ \\
\hline $4395 \mathrm{~N}$ & $\approx 5$ & 10 & $918-1091$ \\
\hline
\end{tabular}

Tabela 2. Materijali i postupci za nanošenje

Table 2. Materials and coating g procedures

Nizak stepen mešanja ( $11 \%$ i $10 \%)$ se postiže u uzorcima obloženim dodatnim materijalima PG6503, 55586C i 4395. Maksimalna tvrdoća se postiže u uzorcima obloženim legurom 4395 (MMA) i 4010EC. Merenje tvrdoće obavlja se na svim uzorcima i opseg vrednosti je prikazan u tabeli 2 . Vrednosti tvrdoće zavise od tačke koja se ispituje, naneti slojevi su veoma krhki i zavise od mogućnosti uređaja. Proces merenja je izveden je po poprečnom preseku modalno obloženih uzoraka.
The low degree of mixing $(11 \%$ and $10 \%)$ is achieved in coated samples with filler material PG6503, 55586C and 4395. The maximum of hardness is achieved in samples coated with alloy 4395 (MMA) and 4010EC. Measurement of hardness distribution is done for all samples and range of values is presented in the Table 2. Values of hardness depend of point which is tested, coating layers is very tick and depend if the device possibilities. Process of measurement has been done thru cross section of modal coated samples.
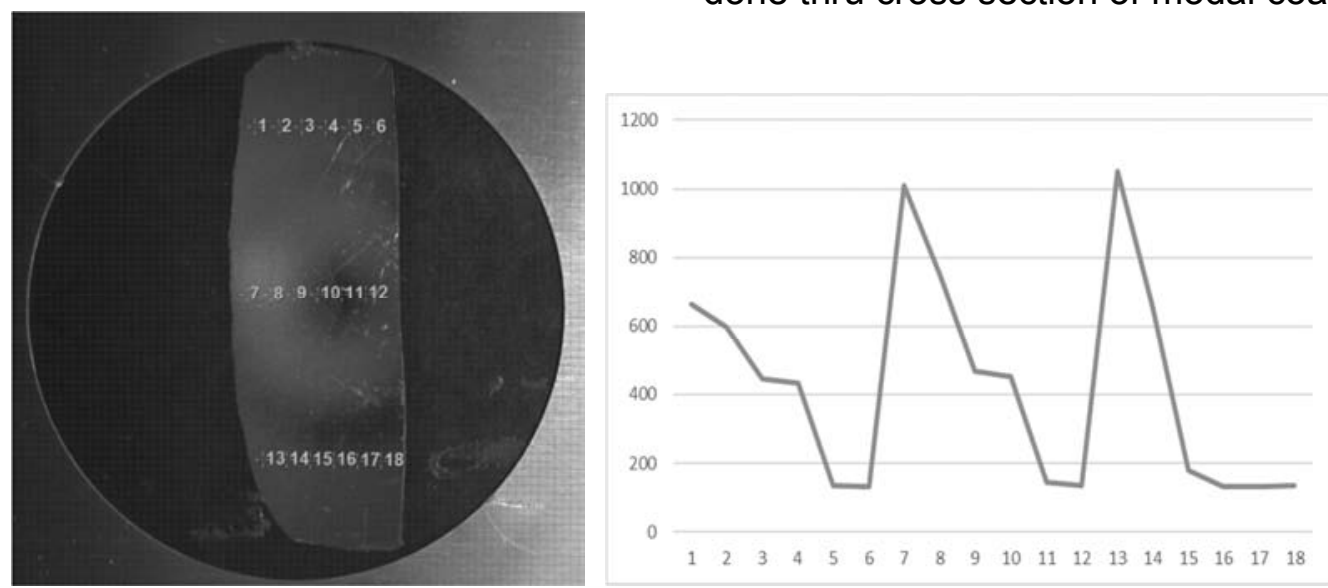

Slika 5. Makrostruktura i distribucija tvrdoće na poprečnom preseku uzorka sa dodatnim materijalom PG 6503

Figure 5. Macrostructure and hardness distribution on the sample cross section done with filler material PG 6503. 
Karakteristika nanetih slojeva i varijacije tvrdoće mogu se objasniti raspodelom različitih faza duž dubine nanosa, kao što je očigledno iz mikrostrukturnog istraživanja. Makrostruktura i merenje raspodele tvrdoće preseka metaliziranog uzorka sa tvrdom prevlakom od dodatnog materijala PG 6503 postupkom metalizacije plazma lukom, prikazani su na slici 5. Vrednosti tvrdoće svih uzoraka date su u tabeli 2. Dijagram na slici 5 pokazuje da u blizini površine, tačke 7 i 13 imaju najviše vrednosti tvrdoće i više od $1000 \mathrm{HV}$. Rezultati prikazani u tabeli 2 ukazuju na to da dodatni materijali 4010 EC i $4395 \mathrm{~N}$ pokazuju relativno homogenu raspodelu tvrdoće i mikrostrukture u poprečnom preseku i mnogo veće vrednosti tvrdoće u odnosu na druga dva uzorka.

Vrednosti tvrdoće $u$ ta dva uzorka sa dodatnim materijalima 4010 EC i $4395 \mathrm{~N}$ su veće $20-40 \%$. Pored toga, interval tvrdoće u poprečnom preseku je veći za $10-80 \%$. Ta dva uzorka imaju mnogo veće vrednosti stepena mešanja osnovnog i dodatnog materijala, zbog konvencionalnih postupaka nanošenja (zavarivanja). Vrednosti tvrdoće se razlikuju iako neki dodatni materijali imaju slično hemijsko jedinjenje. To su posledice različitih postupaka oblaganja i tehnologija primene.

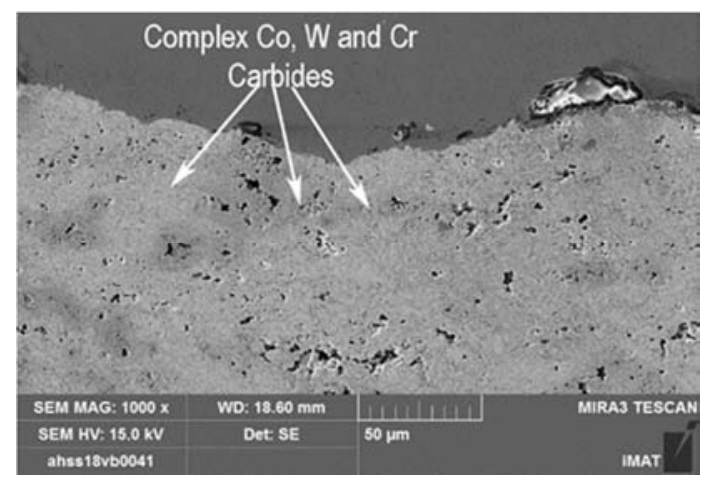

a)

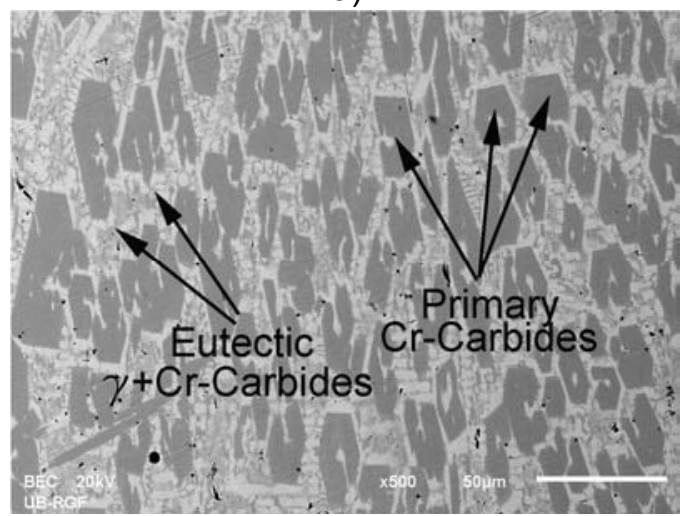

c)
The characteristic of coated layers and the variation in hardness can be explained by the distribution of the different phases along the depth of the coated deposit, as it was evident from microstructuaral investigation. Macrostructure and measurement of hardness distribution of the metalized sample cross section with a hard coating with filler material $P G$ 6503 done with plasma metallization is presented in Figure 5. Hardness values of all samples are given in the table 2. Diagram in figure 5 indicates that in near surface areas, points 7 and 13 has the highest values of hardens in the more than $1000 \mathrm{HV}$. Results show in the Table 2 indicates that a filler material $4010 \mathrm{EC}$ and $4395 \mathrm{~N}$, show relatively homogenous distribution of hardens and microstructure in the cross-section and much higher values of hardness relative to other two samples. Values of hardness in those two samples with filler materials $4010 \mathrm{EC}$ and $4395 \mathrm{~N}$ are higher in $20-40 \%$. Besides that, hardness interval in cross section is higher for $10-80 \%$. Those two samples have much higher values of degree of mixing base material and filer material because are done by conventional process of coating (welding). Values of hardness are different in fact that some filler materials have similar chemical compound. This is consequences of different coating procedures and technologies of applying.

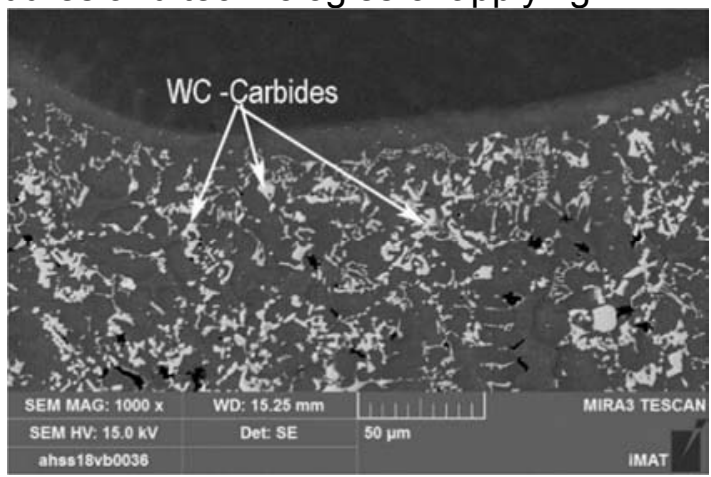

b)

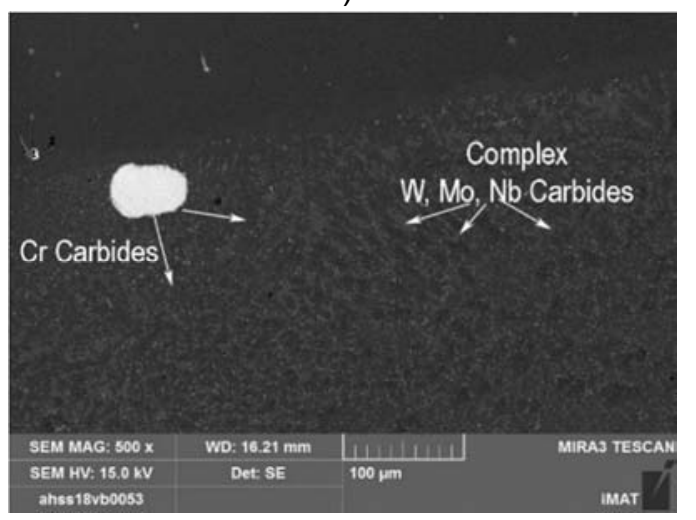

d)

Slika 6. Strukture uzoraka a) - PG6503, b) 55586C, c) 4010 i d) 4395 tvrdi navar

Figure 6. The structures of the samples, a) - PG6503, b) 55586C, c) 4010 and d) 4395 hardfaced coatings 
SEM mikrografije sa EDS različitih faza obloženih uzoraka dodatnim materijalom PG6503, prikazane su na slici 6 . EDS podaci, prikazani u tabeli 3 , ukazuju na različite sastave osnove i prisustvo karbida u nanetom sloju. Struktura blizu površine uzorka sa PG 6503 sastojala se od velikih zrna WC- tačka 2 (svetla faza, slika 7a) i EDS spektra (slika 7b i 7c) ugrađenih u matricu na bazi Ni (tamna faza, slika 7a) i EDS spektar (Slika 7d) u kojima je Fe rastvoren u velikoj količini, dok su Si i $\mathrm{B}$ rastvoreni u manjim količinama. Na mnogim lokacijama su uočene i male čestice WC, crvolikog oblika i slučajne orijentacije.

Raspodela velikih čestica WC $(120 \pm 31 \mu \mathrm{m})$ bila je nejednaka u pravcu debljine prevlake, ali je njihovo prisustvo bilo najveće u površinskom području PG 6503 sloja. Pri oćvršćavanju javljaju se kompleksni karbidi skoro eutektičke strukture i dominantno prisustvo oštrih primarnih $\mathrm{Cr}$-karbida, Cr-borida (slika 6a). U uzorku obloženom sa PG 6503 primetno je prisustvo sitnih ojačavajućih čestica borida / karbida na bazi hroma i njihovo malo rastojanje čestica koje efektivnije ojačava matricu na bazi Ni.

Slika 5b prikazuje strukturu materijala 55586C. Nanošenje materijala pokazuje homogene strukture uz prisustvo poroznosti. Matrica ovog sloja je na Fe bazi a sa eutektičkim W karbidima. Analizirajući sliku 6. može se videti prisustvo kompleksnih Co i $\mathrm{Cr}$ karbida. Uzorak pokazuje homogenu raspodelu karbida sa poligonalnim i sfernim oblikom. Tokom procesa nanošenja, stvoreni su vrlo složeni karbidi, dominantno izgrađeni sa $W$, ali sa spektrom različitih složenih struktura. Plave faze na slici 6 pokazuju dominantno eutektički W-karbid u prisustvu od oko $16 \%$. Ostali kompleksni karbidi su W-Co-Cr oko $27 \%$, Fe-Co-W oko $19 \%$, W-Co-Cr oko $5 \%$ prisustva.
SEM micrographs with EDS of different phases of coated samples with filler material PG6503 are shown in Figure 6. The EDS data, shown in table 3, indicate on different matrix compositions and presence of carbides in coated layer. The nearsurface structure of PG 6503 coating consisted of large WC grains point 2 (light phase, Figure 7a) and EDS spectrum (Figure $7 \mathrm{~b}$ and $7 \mathrm{c}$ ) embedded in the Ni-based matrix (dark phase, Fig. 7a) and EDS spectrum (Figure 7d) in which Fe was dissolved in a major amount, whereas Si and B were dissolved in minor amounts. In many locations, the small, worm-like, and random-oriented WC particles were also observed. The distribution of large WC particles $(120 \pm 31 \mu \mathrm{m})$ was non-uniform in coating's thickness direction but their presence was largest in the near-surface region of PG 6503 coating. During solidification achieves also complex carbides the near-eutectic structure and dominant presence of blade-like primary $\mathrm{Cr}$-carbides, $\mathrm{Cr}$ borides (Figure 6a ). In sample coated with PG 6503 is observed the presence of small chromiumbased boride/carbide reinforcing particles and their short distance between particle which strengthened more effectively the Ni-based matrix. The Figure $5 b$ shows the structure of the material 55586C. Deposition of material shows homogenous structures with presence of porosity. Matrix of this coating is $\mathrm{Fe}$ base matrix with eutectic $\mathrm{W}$ carbides. Analyzing the figure 6 . it can be seen presence of complex $\mathrm{Co}$ and $\mathrm{Cr}$ carbides. Coated sample show a homogeneous distribution of carbides with polygonal and spherical shape. During the process of deposition it's created very complex carbides, dominantly built with $\mathrm{W}$ but it crates various spectrums of complex structures. Blue phases on Figure 6 shows dominantly eutectic W-carbide and presence is around $16 \%$. Other complex carbides are $\mathrm{W}-\mathrm{Co}-\mathrm{Cr}$ around $27 \%$, Fe-Co-W around $19 \%$, $\mathrm{W}-\mathrm{Co}-\mathrm{Cr}-\mathrm{Fe}$ around $5 \%$ of presence.

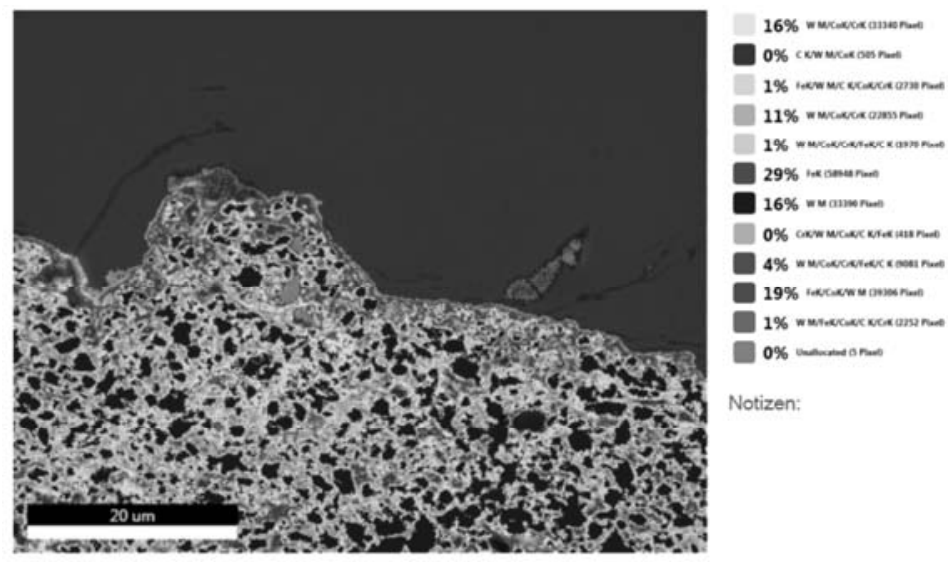

Slika 7. Uzorci obloženi dodatnim materijalom 55586C mapiranje struktura Figure 7. Samples coated with filer material 55586C mapping of structures. 
Struktura dobijenih 4010 obloga sadrži veće šipkaste primarne Cr-karbide sa potpunim odsustvom morfologije tipa lopatice (Slika 5c). Ovi rezultati su u saglasnosti sa dosadašnjim nalazima istraživanja $[12,17,35]$ u kojima dodavanje ugljenika olakšava prelazak iz oštrice prema morfologiji nalik štapu. Morfologija nalik štapu je superiorna kada se razmatraju primene u trošenju. Povećanje zapreminske frakcije Cr-karbida je verovatno rezultat dodavanja ugljenika i hroma [17, $18,26,35]$. Istaknuto je da se veliki primarni karbidi, koji su identificirani kao ( $\mathrm{Cr}, \mathrm{Fe}) 7 \mathrm{C}$, formiraju iz rastopa elektrode (za tvrdo navarivanje) i pokazuju stubičasti rast sa šestougaonim poprečnim presekom.

Međutim, uzorci obloženi dodatnim materijalima 4395, pokazuju homogenu raspodelu karbida sa poligonalnim i sferičnim oblikom. Prikazani podaci EDS ukazuju da je naneti sloj, faza sa visokim sadržajem W, Cr, Nb, Mo i C. Prisutni karbidi su primarni, specijalni karbidi tipa WC, MoC, NbC, kompleksni karbidi Fe3 (V, Mo) 3C i Cr-karbidi [3, $12,26]$, Kako se povećava frakcija specijalnog i kompleksnog karbida, poboljšava se tvrdoća i otpornost na habanje [1-3]. SEM mikrografije sa EDS različitih faza, uzoraka obloženih sa PG6503, prikazane su na slici 8 . EDS podaci, prikazani u tabeli 3 , ukazuju na različite sastave matrice i prisustvo karbida u nanetom sloju.

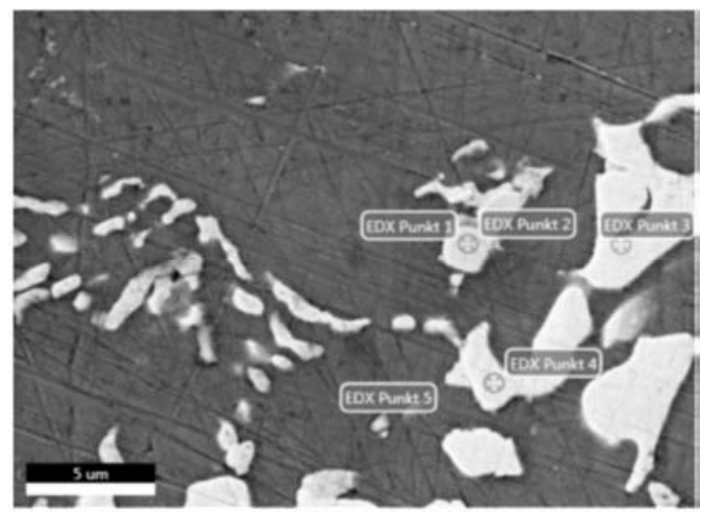

a)

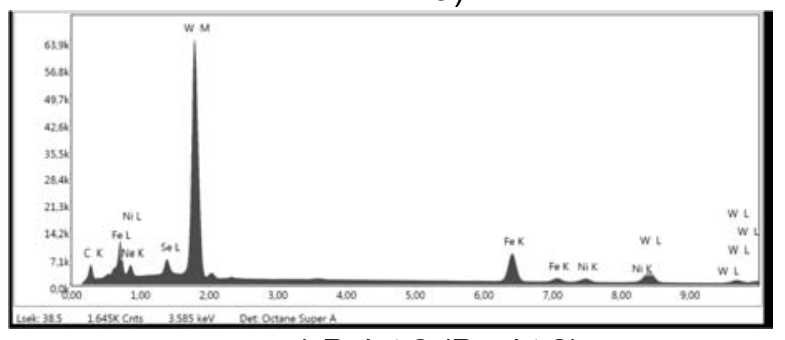

c) Point 2 (Punkt 2)
The structure of the obtained 4010 coatings comprises a larger rod-like primary $\mathrm{Cr}$-carbides with the total absence of the blade-like type of morphology (Figure 5c). These results are in agreement with previous research findings $[12,17$, 35] in which the addition of carbon facilitates transition from blade-like towards the rod-like morphology. The rod-like morphology is superior when wear applications are considered. The increase of the Cr-carbides volume fraction is probably the result of the carbon and chromium addition [17, 18, 26, 35]. It has been point out that large primary carbides, which are identified to be $(\mathrm{Cr}, \mathrm{Fe}) 7 \mathrm{C} 3$, are formed from the melt of the coating (hardfaced) electrodes and exhibit columnar growth with a hexagonal cross section.

However, the samples coated with filler materials 4395 show a homogeneous distribution of carbides with polygonal and spherical shape. The EDS date shown is indicate that coated layer is phase with high content of $\mathrm{W}, \mathrm{Cr}, \mathrm{Nb}, \mathrm{Mo}$ and $\mathrm{C}$. Present carbides are the primary, special carbides type WC, $\mathrm{MoC}, \mathrm{NbC}$, complex carbides Fe3(W, Mo)3C i Crcarbides [3, 12, 26], As the special and complex carbide fraction increases, hardness and wear resistance improve [1-3]. SEM micrographs with EDS of different phases of coated samples PG6503 are shown in Figure 8. The EDS data, shown in table 3 , indicate on different matrix compositions and presence of carbides in coated layer.

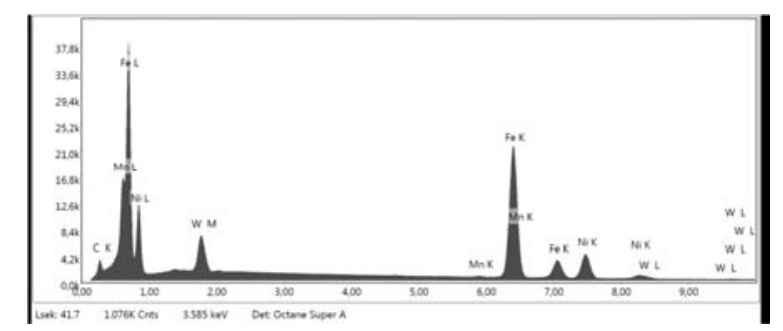

b) Point 1 (Punkt 1)

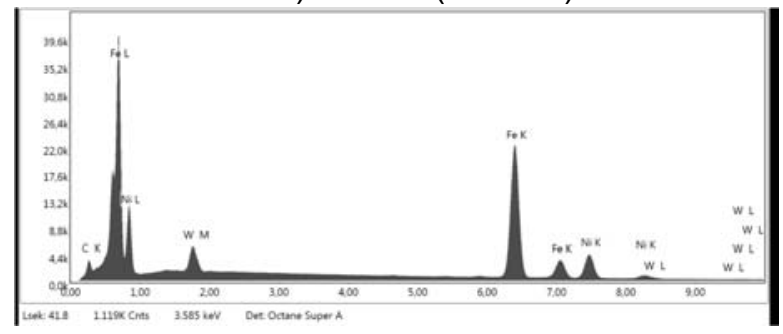

d) Point 5 (Punkt 5)

Slika 7. a) SEM mikrografija i EDS struktura uzorka obloženog sa PG6503

Figure 7. a) SEM micrograph and EDS structure of the coated sample PG6503 


\section{Zaključak}

Numeričke simulacije višefaznog toka izvedene su za ventilacioni mlin u elektrani Kostolac B. Rezultati dobijeni numeričkom simulacijom jasno pokazuju da CFD metode izvršene u ANSISS FLUENT-u pružaju detaljne analize protoka u ventilacionom mlinu sa elementima prepreka u kućici. Numerička analiza određuje uglove pod kojima čestice smeše napuštaju kućicu ventilacionog mlina.

$U$ ovom radu je analiziran odgovarajući ugao ugradnje elemenata prepreka u objektu ventilacionog mlina radi povećanja efikasnosti brušenja. Najviša efikasnost brušenja ventilacionog mlina će biti ako se elementi prepreka na kućici postavljaju direktno u pravcu kretanja većih delova ugljene prašine. Ugao pod kojim čestice uglja napuštaju kućicu mlina uveliko zavisi od koeficijenta trenja između ovih čestica i udarne ploče. Za koeficijent trenja od 0,6 , ugao pod kojim ugljena prašina napušta kanal za prašinu iznosi 29,50 , dok za koeficijent trenja 0,8 taj ugao ima vrednost 25,70.

Definisano je nekoliko geometrija prepreka elemenata pravougaonog preseka, promenjen je njihov ugao i stepen podešavanja. Za centralni ugao od 80 i 120 položaj elemenata prepreka bio je na 450,550 .

Zapreminski udeo ugljene prašine na ulazu $u$ ventilacioni mlin ima vrednost $3,44 \times 10-5$, dok pesak 3,48x10-5. Kada je prisutan fiksni ugao elemenata prepreka, primećuje se da povećanje koraka između elemenata dovodi do mnogo ravnomernije raspodele ugljene prašine u području radnog točka, između elemenata prepreka i kanala za prašinu. Uticaj ugla postavljanja elemenata prepreka i njihovih koraka analizira se modelom mešavine, koja daje pouzdane vrednosti statičkog pritiska na izlazu iz kanala za prašinu.

Lagrangeov model za praćenje čvrstih granuliranih faza je pokazao, da se pri povećanju veličine čestica ugljene prašine, povećava broj njihovih udara na elemente prepreka, dok manje čestice, usled manje inercije, prate tok gasne faze. i kreću se duž zida ventilacionog mlina i imaju manje uglove napada na zidove kanala za prašinu. Ovo je još izraženije kod čestica peska zbog njihove veće inercije, tako da se putevi različitih prečnika čestica veoma razlikuju po površini elemenata prepreka.

Otpornost na habanje određena je veličinom, oblikom, raspodelom i hemijskim sastavom karbida, kao i mikrostrukturom matrice. Da bi se procenilo ponašanje trošenja različitih legura na bazi $\mathrm{Fe}, \mathrm{Ni}$, Co, važno je uzeti u obzir makro tvrdoću i mikrostrukturu i postaviti ih u odnos.

\section{Conclusion}

The numerical simulations of the multiphase flow are performed for a ventilation mill in the Kostolac $B$ power plant. The results obtained by the numerical simulation clearly show that the CFD methods done in ANSYSS FLUENT provide detailed analyses of flow in ventilation mill with obstacles element in house. Numerical analysis determines angles under which particles of mixture leave the house of ventilation mill. In this paper is done analyze appropriate angle of obstacles element installation in the house of ventilation mill to increase the grinding efficiency. The most efficiency of ventilation mill grinding will be if the obstacles elements on the house are set directly in the direction of movement of larger parts of coal dust. The angle at which coal particles leave the house of mill depends largely on the friction coefficient between these particles and the impact plate. For the friction coefficient of 0.6 , the angle at which the coal dust leaves the dust channel is 29.50 , while for the coefficient of friction 0.8 this angle has a value of 25.70. Several geometries of obstacles elements of rectangular cross-section are defined, and their setting angle and step are changed. For the central angle of 80 and 120 the position of obstacles elements was at 450,550 . The volume fraction of coal dust at the entrance to the ventilation mill has a value of $3.44 \cdot 10-5$, and sand $3.48 \cdot 10-5$. When is present the fixed angle of obstacles elements, it is noted that increasing the step between the elements leads to a much evener distribution of coal dust in the area of the working wheel, between the obstacles elements, and in the dust channel. The influence of the angle of setting the obstacles elements and their steps is analyzed by the model of the mixture, which gives the reliable values of the static pressure at the exit of the dust channel. The Lagrange model for the tracking of solid granular phases has shown that when increasing the particle size of coal dust, the number of their impacts on the obstacles elements increases, while the smaller particles, due to less inertia, follow the flow of the gaseous phase and move along the wall of ventilation mill, and have smaller attack angles to the walls of the dust channel. This is even more pronounced in sand particles due to their higher inertia, so that the paths of different diameters particles are very different in area of obstacles elements. Wear resistance is determined by the size, shape, distribution and chemical composition of the carbides, as well as by the matrix microstructure. To evaluate the wear behavior of the different $\mathrm{Fe}, \mathrm{NI}$, Co-based coating alloys it is Koji kriterijumi su primenjeni u selekciji: radni 
uslovi, otpornost na abraziju, zahtevani kvalitet završne obrade, dozvoljena debljina, poroznost sloja i koheziona čvrstoća osnovnog i primenjenog sloja, karakteristike osnovnog materijala, oblik i veličina radnog komada i troškovi celog procesa.

U mikrostrukturi, karbidi u nanetom sloju su različitog oblika, veličine i sastava u zavisnosti od hemijskog sastava dodatnog materijala. $U$ belim gvožđima sa visokim sadržajem $\mathrm{Cr}$ karbida u dominantnoj formi šipki, a u legurama legiranim sa $\mathrm{Ti}, \mathrm{W}, \mathrm{Nb}, \mathrm{B}, \mathrm{Mo}$, itd. postoje i kompleksi poligonalnih karbida i sfernih veličina. Tvrdoća nanetih slojeva povećava se sa većim prisustvom složenih karbida poligonalnih i sferičnih veličina. Slojevi manje tvrdoće pokazali su manju otpornost na abrazivno trošenje, ali je zavisnost (tvrdoća od brzine istrošenosti) bila nelinearna.

Analizirajući, može se zaključiti da broj prepreka u kući ventilacionog mlina što bliže radnom točku, povećava broj mogućih sudara čestica uglja. Na ovaj način postiže se povećanje idealne površine i efikasnosti brušenja iza radnog točka sa udarnim pločama. Promenom oblika prepreka, poprečnog preseka i ugla ugradnje postiže se dodatno povećanje njegove idealne površine što poboljšava kvalitet sušenja mlina. Svi ovi rezultati učestvuju u povećanju kvaliteta ugljene prašine.

Proces protoka uglja u ventilacionom mlinu sa elementima prepreka se izbjgava nepotrebna recirkulacija čestica minerala, peska i uglja, kao i dela transportnog fluida iz separatora ugljene prašine u mlin. $\mathrm{Na}$ ovaj način, značajno je smanjeno trošenje radnih elemenata mlina, posebno udarnih ploča radnog točka, jer je u ovom procesu došlo do trošenja prepreka, što je produžilo preostali radni vek ovih mlinova. .

Analizom obloženih uzoraka i procesa nanošenja sloja može se zaključiti da dodatni PG6503 pokazuje najbolji potencijal otpornosti na habanje distribucijom mikrokonstituenata, gde se analizira tvrdoća i distribucija mikrokonstituenata. Ali i drugi materijali imaju dobar potencijal otpornosti na habanje. Obloženi uzorci će biti analizirani simulacijom trošenja u eksperimentalnim uslovima. Primena ovog sloja će se koristiti i za oblaganje prepreka u ventilacionom mlinu.

Primena ovih dodatnih materijala za buduće rekonstrukcije mora biti podržana dodatnim testiranjem. Ovde je moguće koristiti simulaciju trošenja u mašinama za peskarenje sa peskom kao abrazivnim medijem. Potrebno je koristiti uglove napada koji se mešaju oko elemenata prepreka dobijenih numeričkom simulacijom. Multidisciplinarna istraživanja koja se koriste u ovom radu mogu dati dobre rezultate u smislu important to regard the macro hardness and the microstructure and to set them into relation.

The which criteria were applied in the selection: working conditions, abrasion resistance, required finishing quality, permissible thickness, porosity of the layer and cohesion strength of the base and applied layer, characteristics of the basic material, shape and size of the work piece and costs of whole process.

In the microstructure, coated carbides were noticed with different shape, size and composition depending on the chemical composition of filler material. In white irons with high contents of $\mathrm{Cr}$ carbides in dominate form of bars, and in alloys alloyed with $\mathrm{Ti}, \mathrm{W}, \mathrm{Nb}, \mathrm{B}, \mathrm{Mo}$, etc. there are also complex of polygonal carbides and spherical sizes. Coated layers hardness increases with a greater presence of complex carbides of polygonal and spherical sizes. Coatings with lower hardness showed lower abrasive wear resistance, but the dependence (hardness vs. wear rate) was nonlinear.

Analyzing, it can be concluded that as the number of obstacles in the house of ventilation mill set as close as possible to the working wheel increases the number of possible collisions of coal particles. In this way, an increase in the ideal surface and grinding efficiency is achieved behind the working wheel with impact plates. By changing the shape of the obstacles, the cross-section and the angle of installation, an additional increase in its ideal surface is achieved, which improves the drying quality of the mill. All this results participate in an increase in the quality of coal dust.

The flow process of grinding coal in a ventilation mill with obstacles elements is avoided by the unnecessary recirculation of particles of minerals, sand and coil as well as of the part of the transport fluid from the coal dust separator into the mill. In this way, the wear of the working elements of the mill, in particular the impact plates of working wheel, has been significantly reduced, since part of this process has been brought wear of obstacles, which has prolonged the remaining working life of these mills.

Analyzing the coated samples, and process of deposition of coating it can be concluded that filler material PG6503 show best wear resistance potential by distribution of microconstituents, where is analyzed hardness and distribution of microconstituent's. But other materials also have good potential of wear resistance. Coated samples will be analyzed by simulation of wear in experimental condition. Application of this coating will be used also for coating of obstacles elements 
smanjenja trošenja radnih elemenata ventilacionog mlina i produženja njihovog veka trajanja, čime se olakšava eksploatacija uglja uz manji broj zaustavljanja u eksploataciji.

\section{Priznanja}

Ovaj rad je rezultat istraživanja u okviru projekta TR 34028, kojeg finansijski podržavaju Ministarstvo prosvete, nauke i tehnološkog razvoja Srbije, Messer Tehnogas i PD TE - KO Kostolac.

\section{References}

1. KOZIĆ M, RISTIĆ S, PUHARIĆ M, KATAVIĆ B, PRVULOVIĆ M, "Comparison of Numerical and Experimental Results for Multiphase Flow in Duct System of Thermal Power Plant," Scientific Technical Review, Vol. 60, 2010, p. 39-47,.

2. MIRKO KOZIC, SLAVICA RISTIC, BORIS KATAVIC, MIRJANA PUHARIC, "Redesign of impact plates of ventilation mill based on $3 \mathrm{D}$ numerical simulation of multiphase flow around a grinding wheel" Fuel Processing Technology, FUPROC-03583; 2012, No of Pages 14,

3. Metals Handbook, 9th ed., Volume 18, Friction, lubrication and wear, ASM, Metals Park, Ohio, ISBN9781-61503-163-4, 1993, pp. 320-380.

4. M. KAZEMIPOUR - H. SHOKROLLAHI - SH. SHARAFI, The Influence of the Matrix Microstructure on Abrasive Wear Resistance of Heat-Treated $\mathrm{Fe}-32 \mathrm{Cr}-$ 4.5C wt\% Hardfacing Alloy, Tribol Lett vol.39, 2010, p. 181-192.

5. B. PERKOVIĆ, A. MAZURKIJEVIČ, V. TARASEK, LJ. STEVIĆ, Reconstruction, and realization of the projected modernization of power block B2 in the TE Costal, Termotehnika 1, 2004, p.57-81.

6. M. KOZIĆ, S. RISTIĆ, M. PUHARIĆ, B. KATAVIĆ, M. PRVULOVIĆ, Comparison of numerical and experimental results for multiphase flow in duct system of thermal power plant, Scientific Technical Review, Vol. 60, 2010, p.39-47.

7. KAMALESH S. BHAMBARE, ZHANHUA MA, LU. PISI, CFD modeling of MPS coal mill with moisture evaporation, Fuel Processing Technology Vol. 91, 2010, pp 566-571. in ventilation mill. The application of these filler materials for future reconstructions is must be supported with additional testing. Here is possible to use simulation of wear in sandblasting machinery with sand as abrasive medium. It necessary to use attack angles which mixture flow around obstacles elements which are obtained from numerical simulation. Multidisciplinary research used in this paper can give good results in terms of reducing the wear of the working elements of the ventilation mill and extending their lifetime, and thus facilitating coil exploitation with a smaller number of stops in exploitation.

\section{Acknowledgements}

This paper is the result of research within the project TR 34028 , which is financially supported by Ministry of Education, Science and Technological Development of Serbia, Messer Tehnogas and PD TE - KO Kostolac.

8. European Product Catalogue, Wear and Fusion Technology, Castolin Eutectic International Co, Vienna. 9. YI ZHOU, ZHIQIANG HUANG, FUXIAO ZHANG, SHUANG JING, ZHEN CHEN, YACHAO MA, GANG LI, HAITAO REN, Experimental study of WC-Co cemented carbide air impact rotary drill teeth based on failure analysis, Engineering Failure Analysis, vol. 36, 2013, p. 186-198

10. Thermo investigation and analysis of boiler plant blocks B1 and B2 in Kostolac TE, PD Ltd. Productiontechnical sector, 2014, (internal study).

11. B. KATAVIĆ, B. JEGDIĆ, M. PROKOLAB, M. PRVULOVIĆ, STEVAN BUDIMIR, Z. MILUTINOVIĆ, Optimal Parameters Estimation by the Analytical Methods for the Welding of the GS-36Mn5 Steel, Congress Welding 2012 \& NDT 2012 / Proceedings of abstracts, ISBN 987-86-82585-10-7, 2012. p 51-51

12. CHAO LIU, DONGXIANG JIANG, FULEI CHU, JINGMING CHEN, Crack cause analysis of pulverizing wheel in fan mill of $600 \mathrm{MW}$ steam turbine unit, Engineering Failure Analysis, vol. 42, No. 2, 2014, p. 6073

12. A. ALIL, B. KATAVIĆ, M. RISTIĆ, D. JOVANOVIĆ, M. PROKOLAB, S. BUDIMIR, M. KOČIĆ, Structural and mechanical properties of different hard welded coatings for impact plate for ventilation mill, Welding and Material Testing 3 ,2011, p.7-11 (ISSN 1453-0392).,

13. E. GERCEKCIOGLU, D. ODABAS, E. DAGASAN, Effect of Impact Angle on the Erosive Wear Rate of Dual- phase (DP) AISI 1020, AISI 1040, AISI 4140 and AISI 8620 Steels, Journal of the Balkan Tribological Association, 2009, p. 25-35, Book 1, (ISNN 1310-4772) 14. M.F. BUCHELY, J.C. GUTIERREZ, L.M. LE'ON, A. TORO., "The effect of microstructure on abrasive wear of hardfacing alloys", Wear 259, 2005, p.52-61. 